\title{
Kansanterveydellinen lainsäädäntömme
}

Kirjoittanut Leo A. Kaprio.

Terveydenhoitotyön järjestämiseksi ja terveyden- ja sairaanhoidon tarpeen tyydyttämiseksi on yhteiskuntamme joutunut ja joutuu jatkuvasti säätämään joukon lakeja ja asetuksia, jotka vähitellen tulevat muodostamaan elimellisen kokonaisuuden.

Pohjan yhteiskuntamme terveydenhoidolle muodostavat terveydenhoitolaki ja terveydenhoitosääntö sekä ne lait, jotka määrittelevät terveydenhoidon palveluksessa olevien toimihenkilöiden aseman ja tehtävät. Näitä ovat laki lääkärintoimen harjoittamisesta, laki yleisestä lääkärinhoidosta, laki kunnallisista terveyssisarista sekä laki kunnankätilöistä. Tähän ryhmään toivottavasti tulee lähitulevaisuudessa lisää laki kunnallisista kodinhoitajista.

Lääkärien, terveyssisarien ja kätilöiden erästä tärkeätä työmuotoa säătää laki kunnallisista äitiys- ja lastenneuvoloista. Tällä lailla on myös erittäin suuri väestöpoliittinen merkitys, ja siihen liittyvätkin tavallaan äitiysavustuslaki sekä tekeillä oleva äitiyssuojelulaki, jotka ovatkin enemmän väestöpoliittisia kuin terveydenhoidollisia. Imeväis- ja leikki-ikäisten lasten terveydenhoidon ollessa neuvolain järjestämän työn kohteena, on kansakoululasten terveydenhoidon järjestämisestä määräyksiä useammassa eri laissa.

Paitsi edellämainittuja yleisluontoisia lakeja on olemassa määrättyihin laajan levinneisyytensä tai erikoisen vaarallisuutensa takia yhteiskunnalle merkityksellisiin sairauksiin ja niihin verrattaviin tiloihin kohdistuvia lakeja ja säädöksiä. Tällaisia ovat rokotuslaki, sukupuolitautilaki, mielisairaslaki, ammattitautilaki ja tuberkuloosiasetus. Nämä tukevat ja järjestävät vastaavien sairauksien ehkäi- 
sy- ja torjuntatyötä. Aborttilaki, joka tosin on vasta ehdotuksena olemassa, tulee kuulumaan tähän ryhmään.

Oman erikoisen tyyppinsä ehkä lähinnä liittyen mielisairasja aborttilakiin muodostaa sterilisoimislaki.

Varsinaista sairaanhoitoa ja lähinnä sairaalahoitoa ja sairaalalaitoksen järjestelyä koskevat lait eivät kuulu tämän esityksen puitteisiin.

Terveydenhoitolaki ja terveydenhoitosääntö ovat molemmat vuodelta 1927 ja sisältävät sekä kaupunki- että kauppala- ja maalaiskunnan yleistä terveydenhoitoa koskevat määräykset. Ne säätävät mm. jokaiseen kuntaan asetettavaksi terveydenhoitolautakunnan yleistä terveydenhoitoa johtamaan. Terveydenhoitolautakunnat eivät kuitenkaan toistaiseksi ole läheskään kaikkialla toimineet niin tehokkaasti kuin niiltä voisi odottaa. Lakikin valitettavasti sallii eräissä tapauksissa kunnallislautakuntien samalla toimia terveydenhoitolautakuntina, mutta käytännössä tällainen järjestely merkitsee terveydenhoidollisten asioiden jäämistä aivan taka-alalle kunnallisissa johtoelimissä. Lääkintöhallitus pyrkiikin nykyisin erityisesti tehostamaan terveydenhoitolautakuntien toimintaa. Vilkkaasti toimivalla terveydenhoitolautakunnalla olisi mahdollisuus kiinnittää myöskin alaansa kuuluviin väestöpoliittisiin asioihin enemmän niiden ansaitsemaa huomiota. Esim. nykyisin on terveydenhoitolautakunta sterilisoimisasioissa tärkeimpiä aloitteentekijöitä, mutta. lautakuntien ainakin tässä suhteessa uneliaan toiminnan takia on tämäkin puoli jäänyt miltei kokonaan hoitamatta koko maassa. Terveydenhoitolautakunnalla on laajat tehtävät $\mathrm{mm}$. kulkutautien vastustamistyössä, desinfektiossa, syöpäläisten hävittämisessä, asunnontarkastuksessa, terveyskaitsijoiden työn johtamisessa jne., joihin täsä yhteydessä ei ole syytä tarkemmin puuttua.

Laki lääkärintoimen harjoittamisesta vuodelta 1925 määrää lääkärien pätevyydestä ja yleisistä velvollisuuksista, mutta vasta laki yleisestä lääkärinhoidosta, joka on annettu v. 1939 , mutta astui voimaan v. 1943, määrittelee tarkemmin lääkärien tehtävät yleisen terveydenhoidon palveluksessa. Se sitoo samalla kunnanlääkärin kiinni varsinaiseen terveydenhoitotyöhön, määritellen hänen tehtävänsä virkalääkärinä, eri neuvoloiden lääkärinä sekä koululääkärinä. Vasta tämän lain perusteella tuli kunnanlääkäri omalta osal- 
taan vastuulliseksi myöskin kuntansa terveydenhoidosta eikä yksinomaan sairaanhoidosta. Käytännössä on useimpien kunnanlääkärien työtaakka sairaanhoitotehtävien runsauden takia vielä niin suuri, ettei ilman kunnanlääkäripiirien huomattavaa supistamista tai kunnanlääkärin työn jakamista saman kunnan alueella kahdelle tai useammalle lääkärille saada tarpeellista lääkärịtyövoimaa irti ainakaan maaseudulla terveydenhoidolliseen ja siten myös väestöpoliittiseen työhön. Lääkintöhallitus suunnitteleekin huomattavaa kunnanlääkäripiirien lukumäärän lisäämistä lähivuosina.

Lait kunnallisista terveyssisarista ja kunnankätilöistä, molemmat vuodelta 1944, järjestävät näiden toimihenkilöiden työn lakisääteiselle pohjalle ja velvoittavat samalla heidät toimimaan $\mathrm{mm}$. neuvolatyössä, missä heillä on mahdollisuus, etenkin jos he ovat väestöpoliittisesti valveutuneita, aivan ratkaisevasti vaikuttaa suuren yleisön suhtautumiseen väestökysymyksen ratkaisun kannalta niin tärkeisiin kysymyksiin kuin äitiyden arvon nostamiseen ja suuren lapsimäärän kunnioittamiseen.

Laki kunnallisista äitiys- ja lastenneuvoloista, joka myöskin on vuadelta 1944, on väestöpoliittisesti suurimerkityksinen. Onhan käytännössä todettu, että neuvolatoiminnan avulla voidaan erityisesti imeväis- ja yleensä lasten kuolleisuus saada huomattavasti alenemaan. Säännölliset tarkastukset, äitien valistaminen, suojarokotukset, suojaravinnon järjestäminen j.n.e. ovat kaikki omalta osaltaan tähän tulokseen vaikuttamassa. Viime vuosina on vastasyntyneistä maassamme ensimmäisellä ikävuodellaan kuollut n. 7 \%. Ruotsissa oli vastaava luku vuonna $19422,9 \%$ ja meillä Suomessakin on kuntia, joissa voimakkaalla neuvolasta johdetulla valistas- ja terveydenhoitotoiminnalla on, huolimatta sotavuosien erikoisista olosuhteista, saatu imeväiskuolleisuus laskemaan sotaaedeltäneestä yli $10 \%$ :sta $3 \%$ :iin. Äitiysneuvonta on myöskin erittäin tärkeätä. Äideistä säännöllisesti otettavien veritutkimusten avulla on mahdollista todeta ja ajoissa hoitaa äideissä meillä valitettavan usein piilevänä esiintyvä kuppatauti, joka hoitamatta veisi sikiön melko varmaan kuolemaan tai toisi maailmaan heikon ja vajaakelpoisen lapsen. Åidin joutuessa heti raskauden alussa hoitoon sairautensa takia voidaan lapsi usejmmissa tapauksissa pelastaa täyșin terveenä elämälle. Äitiysneuvontatyön tehokkuutta haittaa se 
seikka, että maassamme on aivan riittämättömästi erikoislääkärien johdossa olevia sairaaloiden synnytysosastoja, joihin neuvoloissa mahdollisesti todetut odotettavissa olevat vaikeat synnytystapaukset voitaisiin ohjata.

Neuvoloissa saavat äidit tietää äitiysavustuksesta sekä toivottavasti jo lähitulevaisuudessa äitiyssuojelulain heille tuomista eduista. Näiden etujen saaminen onkin osaltaan kytketty asianomaisen äidin säännölliseen neuvolassa käyntiin. Neuvolan tehtävänä on lisäksi opastaa äitejä tarkoituksenmukaisesti käyttämään hyväkseen saamiaan äitiys- ja perhelisäavustuksia.

Neuvoloita on maassamme viime vuosina perustettu jo ennen - lain voimaantuloa Mannerheim-liiton, Suomen Huollon ym. aloitteesta ja toimesta lähes neljäsataa. Kun laki on täysin toteutettu, tulee niitä olemaan jokaisessa kunnassa, eräissä useampiakin.

Imeväisten ja leikki-ikäisten lasten huoltoon liittyy luonnollisena jatkona koululasten terveydenhuolto. Mitään varsinaista koulujen terveydenhoitolakia meillä ei ole, mutta kansakoululaitosta koskeva lainsäädäntö, kuten kansakoulun kustannuslaki sekä edellämainitut lait yleisestä lääkärinhoidosta ja kunnallisista terveyssisarista, tekevät mahdolliseksi kansakoululasten terveydenhoidon järjestämisen. Oppikoulujen samoinkuin muiden koulujen, opistojen sekä korkeakoulujen terveydenhoito on lainsäädännöllisesti täysin järjestämättä.

Kunnanlääkäri on velvollinen toimimaan koululääkärinä, jolloin hänen on suoritettava säännöllisesti lasten tarkastukset sekä valvottava koulujen hygieenisiä olosuhteita. Terveyssisar on velvollinen auttamaan koulunhoitajattaren ominaisuudessa koululääkäriä tarkastustilaisuuksissa, toteuttamaan koululääkärin määräämät toimenpiteet sekä pitämään yhteyttä kotien kanssa. Kunnilla on lisäksi mahdollisuus valtion tukemana edellämainitun kansakoulun kustannuslain nojalla järjestää myös kansakoululasten hampaitten hoito ja huolto.

Kouluissa täytetään jokaisesta oppilaasta terveyskortti, jolla voisi olla nykyistä paljon suurempi yhteiskunnallinen ja väestöpoliittinenkin merkitys etenkin laatukysymystä selviteltäessä, jos siitä voitaisiin kehittää jatkuvasti yksilön mukana kuljetettava térveyskortti tai se muuten olisi esim. jonkinlaisessa keskuskortistossa viranomaisten käytettävissä. 
Seuraavina selostettavat erikoislait ovat väestöpoliittisesti tällä hetkellä hyvin eriarvoisia. Vuonna 1936 annetulla rokotuslailla ei nykyisin ole mitään välitöntä vaikutusta, mutta kun ajattelee sen edeltäjän, t.s. rokotuspakon vaikutusta isorokkokuolleisuuden nopeaan alenemiseen viime vuosisadan lopulla, on sen merkitys ja tarpeellisuus itsestään selvä.

Vuonna, 1939 annetulla ja 1943 voimaanastuneella sukupuolitautilailla on erittäin suuri ajankohtainen merkitys. Tässä kirjassa on jo toisessa kohdassa selostettu sukupuolitautiẹn laajan levinneisyyden ja nuiden aiheuttamien jälkiseurausten väestöpoliittista merkitystä (ss. $34-36$ ).

Sukupuolitautilaki perustuu kolmeen pääperiaatteeseen. Nämä ovat: 1) jokaisen sukupuolitautia sairastaneen tai tässä suhteessa epäiltävän henkilön on alistuttava lääkärin tutkimukseen, jolloin sekä tutkimus että hoito ovat jokaiselle maksuttomat, mikäli sairas ei halua olla lääkärin hoidossa maksavana yksityispotilaana; 2) kaikki tartunnanlähteet on koetettava ottaa selville ja viipymättä saatettava tehokkaaseen hoitoon; 3) tauti pysyy lääkärin ja potilaan välisenä asiana, niin kauan kuin potilas tarkoin noudattaa lääkärin antamia hoito-ohjeita ja hänen määräämiään varovaisuustoimenpiteitä. Kielteisessä tapauksessa terveydenhoitolautakunta ja pahimmassa tapauksessa poliisiviranomaiset puuttuvat asiaan.

Laki on käytännössä osoittautunut tehokkaaksi ja soveliaaksi aseeksi taistelussa sukupuolitauteja vastaan. Tämän lain ja yleisöön kohdistettavan voimakkaan valistustoiminnan avulla, jota hoitamaan on v. 1945 perustettu erityinen sukupuolitautien vastustamisyhdistys, on toiveita siitä, että yleisen terveydenhoidon ja väestöpolitiikan kannalta katsoen suorastaan tuhoisat nykyiset tautisuusluvut saadaan pian laskemaan.

Vuodelta 1937 oleva mielisairaslaki järjestää tämän väestön laadun kannalta merkityksellisen aineksen hoitoon ottamisen, hoidon ja aseman. Tämä laki tullee lähitulevaisuudessa uudistettavaksi ja, saamaan täydennyksekseen määräyksiä mm. maan jakamisesta psykiatrisiin huoltopiireihin. Kun näihin saadaan pätevät lääkärit johtamaan mielisairaaloiden ja erilaisten laitosten ulkopuolelle jäävien kymmenientuhansien lievästi mielisairaitten, sai- 
rasmielisten ja vajaamielisten huoltoa, voidaan toivoa tälläkin alalla tulevan enemmän käytännöllisiä mahdollisuuksia väestöpoliittisten, lähinnä laadullisten näkökohtien huomioonottamiselle.

Ammattitautilaki vuodelta 1939 määrittelee korvattavat ammattitaudit ja tekee siten järjestelmällisen ammattitautien vastustamistyön mahdolliseksi. Tällä voi taas eräissä yksityiskohdissaan olla suoranaista väestöpoliittista merkitystä esim. silloin, kun sen avulla estetään määrätyssä myrkyllisessä tehdastyössä toimivien naisten myrkytystilan takia alati uudistuvat keskenmenot, mutta muuten lailla on lähinnä yleisluontoinen terveyden- ja sairaanhoidollinen merkitys.

Vuonna 1927 annettu tuberkuloosiasetus saattaa tuberkuloosia sairastavat henkilöt valvonnan alaisiksi, mutta muuten se antaa vain epätäydellisesti tukea tuberkuloosin vastustamistyölle, joka on ollut Tuberkuloosin vastustamisyhdistyksen suurenmoisen työn varassa. Lainsäädäntömme kaipaa tässä suhteessa täydennystä, jotta tuberkuloosin vastustamistyö tulisi virallisesti liitetyksi valtion ja kunnallisiin terveydenhoitoelimiin. Tuberkuloosi on tuhoisin kansantautimme; se vaatii vuosittain monia tuhansia kuolonuhreja parhaassa työkunnossaan olevista ikäluokista. Lisäksi näissä ikäluokissa olevien sairaitten suuri lukumäärä tekee siitä väestöpoliittisesti erittäin haitallisesti vaikuttavan tekijän, jota vastaan olisi kaikin käytettävissä olevin keinoin taisteltava.

Mitään aborttilakia ei maassamme vielä ole, vaikka vuosittain pariinkymmeneentuhanteen nouseva rikollisten raskaudenkeskeyttämisten lukumäärä edellyttäisi joitain lainsäädännöllisiä ja samalla sosiaalisia toimenpiteitä epäkohdan edes osittaiseksi lievittämiseksi. Aborttikomitea on kuitenkin vuonna 1945 saanut valmiiksi ehdotuksensa aborttilaiksi, joka määrittelee ne tapaukset, joissa raskaudenkeskeyttäminen sallitaan. Samalla pyritään ehdotukseen liittyvissä rangaistusmuutosesityksissä ns. aborttiuhrien rangaistuksia huomattavasti lieventämään, jotta varsinaisten ammattimaisten abortintekijöiden kimppuun voitaisiin täydellä teholla käydä. Laki ei kuitenkaan tule vastaamaan tarkoitustaan, jollei samalla voimakkaasti tueta odottavien äitien asemaa $\mathrm{mm}$. hyväksymällä äitiyssuojelulakiehdotus, ja sukuṕuolivalistuksen avulla koeteta väbentää ei-toivottujen raskauksien alkuunpääsemistä. Aborttia ha- 
kevat naiset olisi myös ajoissa saatava oikean henkilökohtaisen valistuksen ja huollon kohteeksi.

Sterilisoimislaki vuodelta 1935 säätää, että tylsämielinen, vähämielinen ja mielisairas voidaan määrätä tehtäväksi suvun jatkamiseen kykenemättömäksi, jos on syytä otaksua, että sellainen vajaakelpoisuus periytyisi hänen jälkeläisiinsä, tai jos on todennäköistä, että hänen lapsensa jäisivät hänen tällaisen vajaakelpoisuutensa takia huoltoa vaille.

Lisäksi voidaan saman lain perusteella luonnottoman sukuvietin omaava eräissä tapauksissa määrätä kastroitavaksi.

Tämä laki, jolla pitäisi voida olla suuri merkitys pyrittäessä kansan laatua parantamaan, ei käytännössä ole osoittautunut tehokkaaksi. Sen toimeenpanokoneisto on melko monimutkainen ja hidas. Sitäpaitsi sinänsä kahden nuin erilaisen toimenpiteen kuin sterilisoimisen ja kastroimisen kytkeminen samaan lakiin on aiheuttanut maallikkopiireissä ymmärrettävää epäluuloa lakia kohtaan. Sterilisoiminen, joka yleensä on täysin vaaraton toimenpide, merkitsee munatorven katkaisua tai sitomista naisilla ja vastaavia toimenpiteitä siemenjohtimeen nähden miehillä. Tämä toimenpide ei millään lailla muuta yksilön luonnetta eikä häiritse hänen sukupuolielämäänsä. Kastroiminen eli sukupuolirauhasten poistaminen on taas tarpeellinen vain aniharvoissa tapauksissa luonnottoman sukuvietin ollessa kyseessä, ja se on todella radikaalinen toimenpide, jolla pyritäänkin muuttamaan vaarallinen yksilö ja tekemään hänet sukupuolisesti kyvyttömäksi, koska hänen sukupuoliviettinsä on ympäristölle vaaraksi.

Sterilisoimisia ei lain voimassaoloaikana ole suoritettu kuin kaikkiaan n. 500, mikä on mitättömän pieni määrä verrattuna jo yksinomaan maamme vähä- ja tylsämielisten lukumäärään (s. 37). Sterilisoimislaista on tekeillä valtion komiteassa uusi lakiehdotus, joka toivottavasti toteutettuna osoittautuu joustavammaksi ja tehokkaammaksi kuin nykyinen.

Kansanterveyttä koskeva lainsäädäntömme ei suinkaan ole täydellinen, ja se on ja sen on oltava jatkuvan kehityksen alaisena. Tällä hetkellä näyttää siltä, että mielisairaitten ja yleensä psyykillisesti vajaakelpoisten huolto samoinkuin tuberkuloosihuolto tulee lähitulevaisuudessa saamaan lainsäätäjältä laajemman tuen. Abortti- 
laista ja sterilisoimislain uusimisesta oli jo puhetta. Myös terveydenhoitolain ajanmukaistaminen on harkittavana. Nivelreumatismin vastustamistyön järjestäminen tulee aikanaan tarvitsemaan lainsäätäjän tukea. Kouluterveydenhoito koko laajuudessaan kaikki koulumuodot käsittävänä on järjestämättä. Avioliittoon aikovien olisi jouduttáva lääkärintarkastukseen, avioliittolakimme kaipaa vastaavaa muutosta.

Kaikilla tämäntapaisilla järjestelyillä on myös välillinen tai välitön väestöpoliittinen merkityksensä. Väestöliitto onkin toimintansa aikana, kuten muussa yhteydessä tarkemmin selostetaan, kiinnittänyt aktiivista huomiota eräisiin näistä laeista ja niiden toimeenpanoon ja soveltamiseen sekä seuraa niitä kaikkia jatkuvasti tehden tarpeen 'vaatiessa omia esityksiä huomaamiensa epäkohtien korjaamiseksi. 